\title{
Structural Interpretation of Lineament from Nlonako Area and Surroundings: Contribution to Pan-African Tectonic Reconstruction
}

\author{
Noudiédié Kamgang Julie Agathe, Tcheumenak Kouémo Jules, Fozing Eric Martial, \\ Kagou Dongmo Armand, Kenfack Roslin Brice
}

\section{ABSTRACT}

The Nlonako anorogenic complex (NAC) is located in the south western part of the Cameroon Line and is superposed on the N50E section of the central Cameroon shear zone. It is suggested to be a ring complex of $10 \mathbf{~ k m}$ diameter which was emplaced as sill intrusive body during the Tertiary. In order to do characterize the Nlonako complex shape and characterize the tectonic history in the study area and surrounding, spatial technology (Landsat 8 ETM+ and SRTM images) were used for geological mapping and structural reconstruction based on lineament analysis.

Data extracted from Landsat 8 ETM and SRTM images show a sub-circular shape for the NAC and the superposition of field and petrographic data from our previous research works confirm the fact that the NAC is a ring or annular complex slightly elongated NNE-SSW, thus it is known as the Nlonako ring complex (NRC). Map of lineament synthesis and the SRTM image of the study area display NE-SW, NW-SE and N-S trend structures. (1) The dominant NE-SW trend mostly displayed by the NRC and its basement rock is parallel to (i) the main metamorphic foliation trend and (ii) to the central Cameroon shear zone regional fault, corresponds to the trending of the regional foliation, structures and the Ngondo pluton elongated shape. (2) The secondary N-S direction may correspond to the late deformational phase in the area because, the N-S-related structures transposing NESW structures towards a meridional direction in the NRC basement rock. (3) The NW-SE trend corresponds to the direction of NW-SE fault cross cutting the NRC.

Field data and synthetic lineament map enable to identify: (1) a Compressive deformational phase $D_{1}$ whose main markers are NNW-SSE to NW-SE $S_{1}$ foliation; (2) an early left-lateral deformational phase $D_{2}$ characterized by anticlockwise rotation of clasts and NE-SW sinistral transposition of early structures; (3) a NE-SW right-lateral deformational phase $D_{3}$ marked by clockwise rotation and dextral transposition of preexisting structures as well as the NE-SW $S_{3}$ foliation and (4) a late left-lateral deformational phase $\mathrm{D}_{4}$ marked by the N-S transposition of NE-SW dextral $D_{3}$-related structures by late sinistral shear movement. This suggests a more complex tectonic history for the Pan-African Belt in Cameroon showing at least three shear phases, that is a right-lateral phase, sandwich by two left-lateral phases.

Keywords: Nlonako, Lineament, ring structures, tectonic reconstruction, PanAfrican.

Published Online: October 7,2020

ISSN: $2684-446 \mathrm{X}$

DOI :10.24018/ejgeo.2020.1.5.67

\section{J. A. Noudiedie Kamgang}

Department of Earth Sciences, Faculty

of Sciences, University of Dschang, Cameroon.

(e-mail: jnoudiedie ${ }^{@}$ gmail.com)

J. Tcheumenak Kouemo *

Department of Earth Sciences, Faculty of Sciences, University of Douala, Cameroon.

(e-mail: tcheumenak2@gmail.com)

\section{Fozing Eric Martial}

Department of Earth Sciences, Faculty of Sciences, University of Dschang, Cameroon.

(e-mail: emfozing@mail.com)

\section{Kagou Dongmo Armand}

Department of Earth Sciences, Faculty of Sciences, University of Dschang, Cameroon.

(e-mail: kagoudongmo@yahoo.fr)

\section{R. B. Kenfack}

Department of Earth Sciences, Faculty of Sciences, University of Dschang, Cameroon.

(e-mail: roslinkenfack@yahoo.fr)

*Corresponding Author

\section{INTRODUCTION}

For many aspects of geological activities, remote sensing has been used as a valuable tool, as from the early days of "geologic remote sensing science" [1] to date. For regional mapping, structural interpretation and prospecting for ores and hydrocarbons, geologists have used space images [2]. Indeed, the advent of spatial technology, has greatly contributed to the improvement of the usual geological mapping methods, especially in developing countries where cartographic documents are incomplete or not updated due to some constraints [3] including the cost, accessibility to dangerous or previously inaccessible sites, the heterogeneity of the information and the interpolation methods of traditional field-based lithological mapping [4]-[7].

Numerous Pan-African plutons such as the Ngondo pluton and Tertiary intrusions such as the Nlonako and Koupé plutons are marked by a dense forest environment and inaccessible sites, underlain by diversified geological formations in Cameroon. Rocks in these area outcrop sometime very rarely, discontinuously and usually highly altered. Therefore, traditional field mapping and tectonic studies are tedious, costly and may also lead to misinterpretation. This is the case of the Nlonako pluton for which round shape and N-S elongated shape are attributed 
by [8] and [9] respectively. Therefore, the use of space images as landsat and Shuttle Radar Topography Mission (SRTM) is necessary to solve the problem of shape of this Tertiary complex. Indeed, data from the late images characterize the morphology, roughness and geometric shapes of the study area [10]. Field data, lineament analysis morphometric data from the Landsat 8 ETM+ and SRTM images were used in this study with the aim of definitely clarifying the shape of the NRC and suggesting the new tectonic history reconstruction of the study area.

\section{GeOlOGicAl SETTING}

The NAC is located in the south western part of the Cameroon Line (CL) and superposed on the N50E branch of the central Cameroon shear zone (Fig. 1, CCSZ). According to [11] this complex was emplaced as sill intrusive body during the Tertiary (45 - $35 \mathrm{Ma},[12]-[14])$ in a Pan-African $\mathrm{k}$-feldspars megacrysts granites and gneiss host rocks under fractures control consecutive to the late Cretaceous general extension. After its emplacement, the NAC experienced the cauldron subsidence of its summit, facilitated by the development of conjugated faults and the downward sliding of rocks along the NW-SE fault, leading to the formation of caldera at its summit [11]. The NAC is made up of syenites, biotite -pyroxene granite gabbro, rhyolite and basalt intruded in granite-gneissic basement [11]. Syenite, which represents the dominant rock type (about $90 \%$ of the rock types) of the NAC, displays porphyritic heterogranular texture made up of quartz, k-feldspar, plagioclase, pyroxene, zircon and opaque minerals. Biotite-pyroxene granites are composed of quartz, k-feldspar, plagioclase, biotite and opaque minerals. Gabbro consists of coarse heterogranular crystals to very fine grained matrix composed of plagioclase, olivine, pyroxene and opaque minerals in which some plagioclase, olivine and pyroxene occur as megacrysts. Diorite display tabular k-feldspar crystals and display very fine to medium grained texture, with plagioclase, $\mathrm{k}$-feldspar and clinopyroxene as medium grained crystals. Rhyolite and basalt outcrop as dyke in syenite and gneiss and displays porphyric microlitic texture. More detailed petrographic data of the NAC are given by [9], [14] and [11]. According to [15], the megacryst granite basement rock of the NAC, is synkinematic granite whose emplacement was totally controlled by a $\mathrm{N} 30^{\circ}$ sinistral shear zone.

\section{METHOD}

The Landsat 8 satellite, whose image was used for the present studies, possessed a radiometer Enhance Thematic Mapper plus (ETM+) and has a spacial resolution of $30 \mathrm{~m}$. The Landsat image used is from the sheet Landsat ETM+ LC 81860572017360 LGN00of the 26 December 2017. The image was then projected to the WGS-84 datum and Universal Transverse Mercator Zone $32 \mathrm{~N}$ coordinate system. The method applied for lithology and structural features identification consisted of visual interpretations of the Landsat 8 ETM+ imagery and manual delimitation of features after textural analysis.

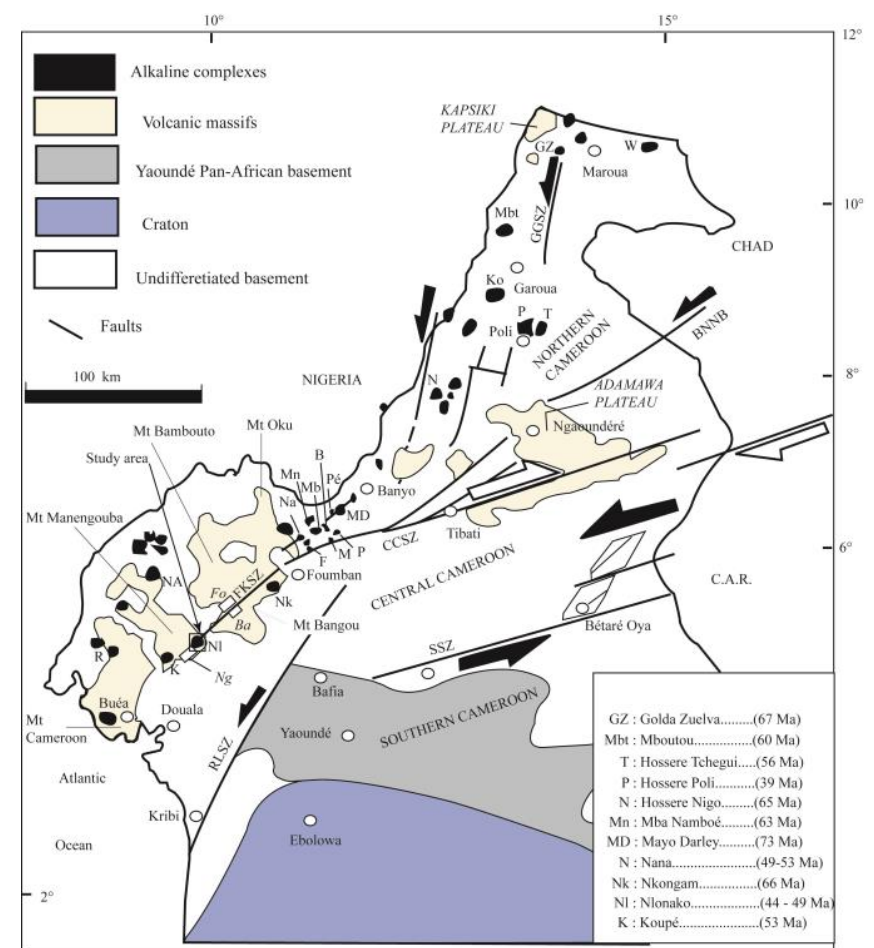

Fig. 1. Location of the study complexes redrawn from [16]. Lower right: age of the anorogenic complexes cropping out along the Cameroon Line. Alkali ring complexes: NA Nda Ali: K: Koupé; F: Fourougain; M: Mbafé; Mb:

Mba Bitou; B: Biridjom; Mn: Mba Namboué; MD; Mayo Darley; Na: Nana; Ni: HosséréNigo; Nl: Nlonako; Nk: Nkongam; P: Pamsa; Pé: Pandé; P:

Hosséré Poli : R: Roumpi; T: Hosséré Tchegui; Ko: Koukoumi ; Mbt:

Mboutou; GZ: Golda Zuelva; W: Waza. Syntectonic plutons: $\mathrm{Ba}$ : Bandja; Fo: Fomopéa; $N g N g o n d o ;$ Shear zones (SZ): BNMB = Buffle Noir- Mayo Baleo SZ; CCSZ = Central Cameroon SZ; GGSZ = Godé-Gormaya SZ; RLSZ = Rocher du Loup SZ; SSZ = Sanaga SZ; FKSZ: Fotouni-Kékem SZ.

Textural analysis consists in quantifying the different gray levels of the image in terms of roughness and distribution. From this contextual analysis technique an image dissimilarities or homogeneous zones can be highlighted on the map. Several methods of texture analysis methods are known. These include structural methods, statistical methods, methods based on the study of forms, spatio frequential methods and fractal [17]. The statistical approach known as Grey Level Co-occurrence Matrix (GLCM) proposed by [18] was adopted in the present study. This method allows the identification and selection of the parameters that enable the best definition the elements from the measurement of the gray tone distributions. Numerous authors developed topics on the application of the GLCM technique in synthetic aperture space images in geological applications [7], [19]-[24]. Executed in ENVI software environment the implementation of GLCM, using a 5x5 window and Pixel offset 1 on the Landsat ETM+ monoband permitted the calculation and creation of normalized co-occurrence used for lineament investigations.

Lineaments are generally related to fractures and lithologic boundaries and in some cases to geomorphic relief, appear therefore on the image with a tonal difference. In geologic investigation, linear features on a satellite image regularly reflect the geological lineaments such as regional foliation, faults or fractures and hydrological structures such as river [25]. Several lineament detection algorithms exist in remote sensing, but those based on filtering techniques using 
directional filters (Sobel) show good results [7], [26]-[33]. The filtering methods principle' main goal is the detection of neighboring pixels which suddenly change in gray level by the use of a differential operation. To extract lineaments, the Principal Component Analysis (PCA) was performed on the co-occurrence indices created. The de-correlation of the different bands and the reduction of the dimensionality of the resulting feature space enhancing the multiband image for structural interpretation purposes were performed using PCA. The main aim here was to use inter-band correlation, to compress textural information from the co-occurrence images to less, and to represent nearly the whole of the available information as applied by [34] and [35]. Directional filters were applied to the image at 0, 45, 90 and 135 for four principal directions (N-S, NE-SW, E-W and SE-NW) respectively, with $5 \times 5$ window to increase frequency and contrast in the image. The structure lines were then extracted manually in GIS software (Argis, for example). Structures clearly identified in the filter directions were considered as major while those observed not in all the directions were considered as minor structures. Major structures were named faults and minor structures named fractures after comparing with geological maps from [8] and [11]. A tentative validation of the results is provided based on SRTM image and our previous [8] conducted in the same area. The SRTM image is an altimetry data of $30 \mathrm{~m}$ to $90 \mathrm{~m}$ precision that facilitate supposed and demonstrated lineament extraction.

\section{RESULTS}

\section{A. Field data}

Investigations during field works enable to identify features such as foliation (metamorphic and magmatic), folds, shear structures, veins and fractures.

Metamorphic foliation is observed in gneiss. It is characterized by quartz-feldspar rich clear and dark ferromagnesian alternative bands in Balondo Nlonako and Ngwa. This foliation displays NE-SW (N30E-N40E) trend, strongly dipping $\left(65^{\circ}-75^{\circ}\right)$ toward the SE which was locality transposed into NW-SE (N143E-N158E) and the N-S direction (N10E 165SE) (Fig. 2a). This foliation is cut across by N165E, N70E and N40E quartz and k-feldspar rich veins (Fig. 2a, 2b) which itself, is affected by conjugated N85E and N125E sinitral shear planes.

Veins are observed in Enyokè, Balondo Nlonako and Singalngal. They are rhyolitic and basaltic in composition and display thicknesses varying from 7 to $13 \mathrm{~cm}$ in Enoykè vein. Veins are also Bt-Cpx granite in composition with thicknesses varying between $5 \mathrm{~cm}$ and $10 \mathrm{~cm}$ and outcrop in syenite and k-feldspar megacrysts granite in Balondo (Fig. 2c, 2d). In k-feldspar megacrysts granite, Bt-Cpx granite displays $\mathrm{N} 20^{\circ} \mathrm{E} 48^{\circ} \mathrm{SE}$ and $\mathrm{N} 35 \mathrm{E} 44 \mathrm{NW}$ conjugated planes whose directions are parallel to k-feldspar megacrysts. In Singalngal, N-S (N10E) and E-W (N95E) k-feldspar megacrysts granite veins with 15 to $45 \mathrm{~cm}$ thickness are observed in gneiss [11].

Fractures are mostly joints and observed in megacrysts granite and gneiss in Balondo Nlonako. This brittle deformation fractured k-feldspar and cut cross one another or cross cut the foliation. Fractures display directions varying from N40E to N155E with strong dips towards SE or SW and grouped into two generations. The first generation (N40E-N80E) is cut across by the second generation $\mathrm{N} 105 \mathrm{E}$ to $\mathrm{N} 155 \mathrm{E}$ (Fig. 2). In k-feldspar megacrysts granite, fractures are oblique to k-feldspar megacrysts.

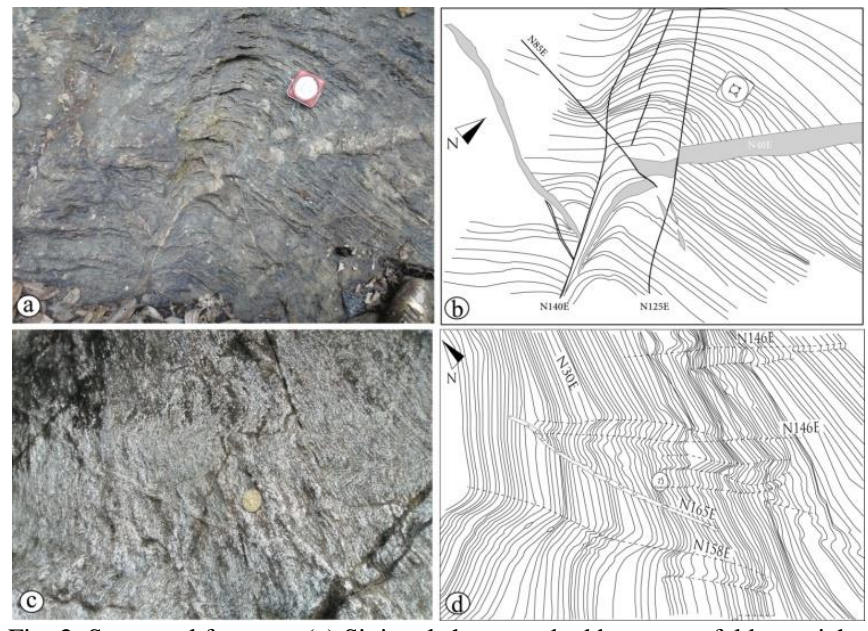

Fig. 2. Structural features. (a) Sinistral shear marked by quartz-feldspar rich vein along $\mathrm{N} 85^{\circ} \mathrm{E}$ and $\mathrm{N} 125^{\circ} \mathrm{E}$ plane. (b) Image redrawn from photo (a) showing sinistral shear movement. (c and d) Transposition of $\mathrm{N} 30^{\circ} \mathrm{E}-$ $\mathrm{N} 40^{\circ} \mathrm{E}$ foliation into $\mathrm{NW}-\mathrm{SE}\left(\mathrm{N} 143^{\circ} \mathrm{E}-\mathrm{N} 165^{\circ} \mathrm{E}\right)$ in gneiss (c). d) Image redrawn from photo (a).

\section{B. Lineament Analyses}

Sobel (5x5) filters applied on Landsat ETM+ image (Fig. 3) following the N-S (N0E andN160E), NE-SW (N45E), EW (N90E) and NW-SE (N135E) enable the identification of lineament, but only those applied in N-S, NE- SW and NW$\mathrm{SE}$ were used because there was a strong similarity between $\mathrm{N}-\mathrm{S}$ and E-W filters.

In the filter applied in the NE-SW direction (Fig. 4), three lineament trends are observed: the NE-SW, the N-S and NW-SE directions. (1) The dominant NE-SW lineaments are cut across and sometimes affected by (2) the N-S sinistral trust fault or lineaments. (3) These N-S lineaments are then cross cut by NW-SE lineaments. Detailed extraction of the lineaments (Fig. 4) shows that in CAN, the linear structures are generally oriented NE-SW. Nevertheless, some curvilinear structures are present and seem to indicate that the complex would be consisted of two rings.

In the filter applied in the NW-SE direction (N135E, Fig. 5), three lineament trends NE-SW, N-S and NW-SE are observed. However, the N-S and NE-SW lineaments are well represented. The NW-SE structures are presented in the NAC, although they are not well expressed as in the filter applied in the NE-SW direction. The circular structures observed in the NAC are more pronounced in this filter (Fig. 5). In addition, the organization of the Nlonako complex into two-rings is becoming more and more pronounced. 


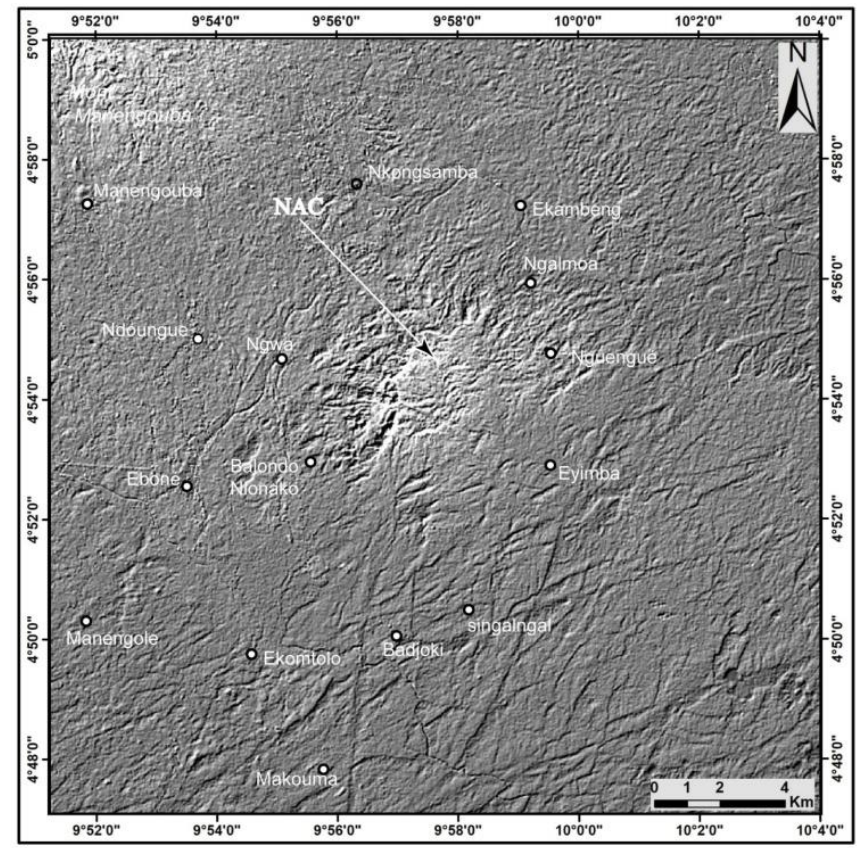

Fig. 3. Landsat ETM+ image of the study area.

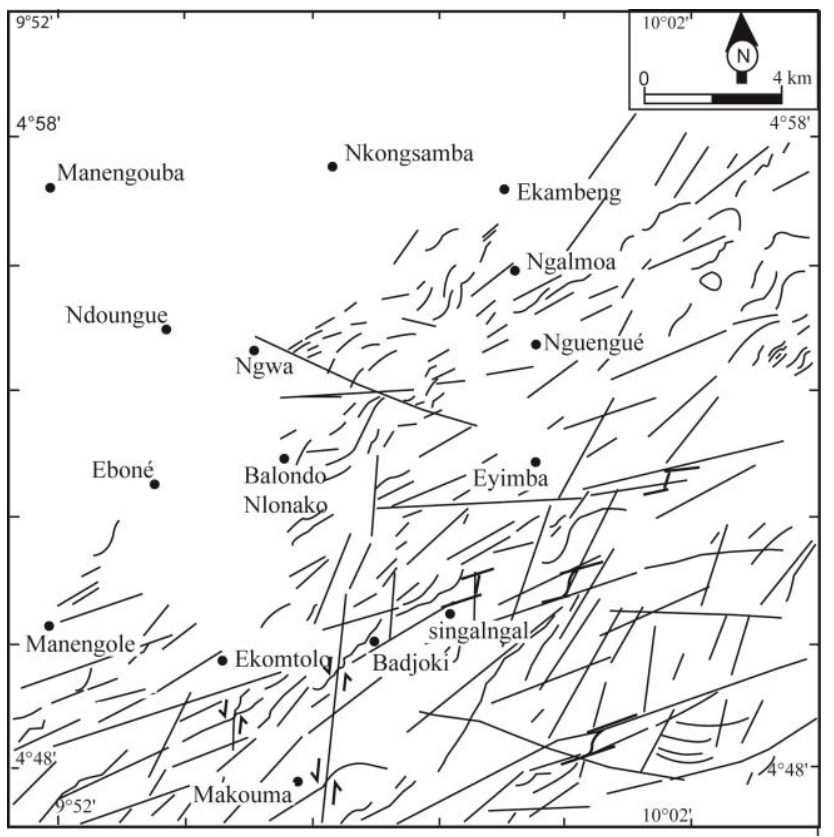

Fig. 4. Extraction of lineaments on Landsat 8 ETM + following the NE-SW direction (N45E).

In the filter applied in the N-S direction (N160E, Fig. 6a), four lineaments directions NE-SW, NNE-SSW, N-S and NW-SE are observed. The NE-SW structures are present only on the smallest rings of the complex, although is not well expressed as in the filter applied in the NE-SW direction. Circular structures (Fig. 6) are pronounced there as on the filters applied in the NW-SE direction (Fig. 4), as well as the occurrence of the complex into two rings.

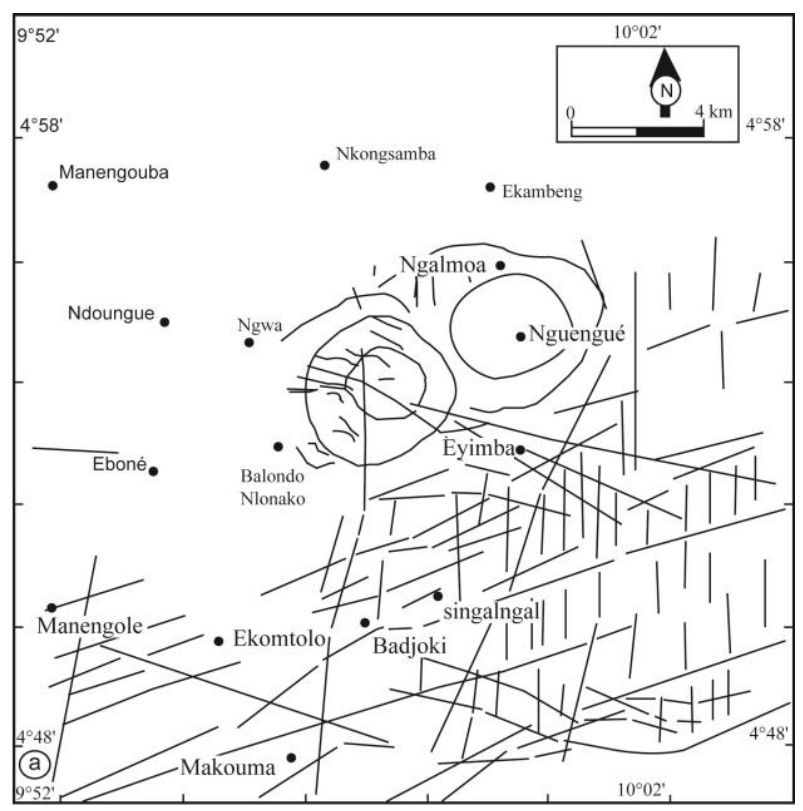

Fig. 5. (a) Landsat 8 ETM + image in monochromatic mode and (b) extraction of lineaments on Landsat $8 \mathrm{ETM}+$ following the NW-SE direction (N135E). (b) stereogram of directions. (c) stereogram of cumulative directions.

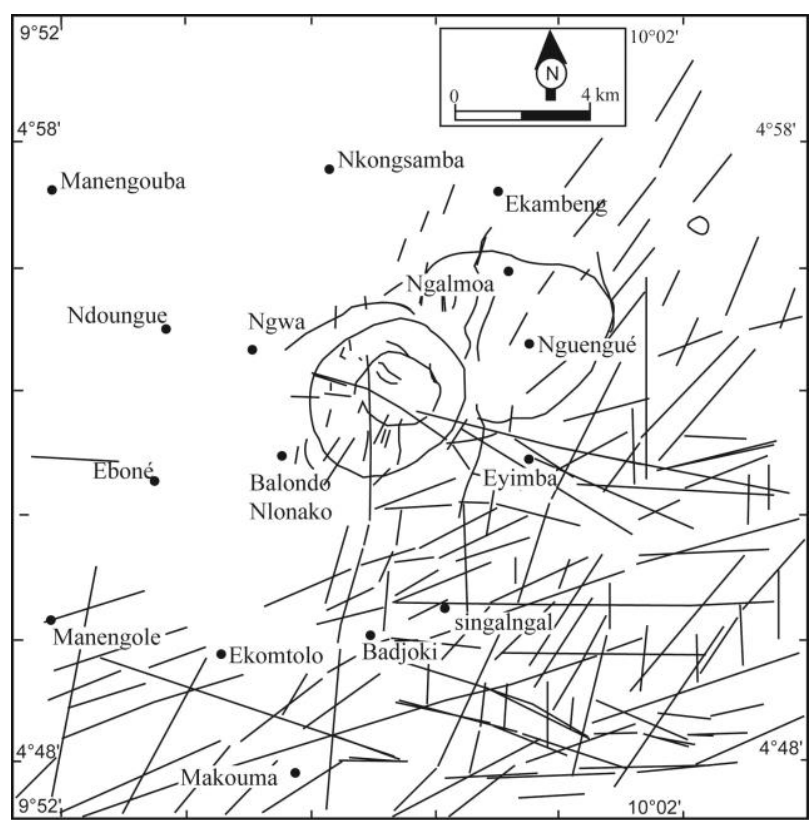

Fig. 6. Extraction of lineaments in the NW-SE direction (N160E).

The map of lineament synthesis presents three directions (Fig. 7a): (1) a NE-SW to ENE-WSW (N50E-N80E, averaged N60E-N70E) dominant direction (2) a secondary N-S (N170E-N10E) direction and (3) an accessory NW-SE direction. Also, NE-SW dextral shear markers are observed in the south of Eyimba and major N-S sinistral strike fault are identified at Ekomtolo and Makoum. Curvilinear and circular structures are observed in the NAC where two rings are identified: the largest and a smallest ring. The largest ring presents inner sub-circulars steep slopes corresponding to the collapsed zone at the top of Mount Nlonako. On the Landsat image, the NE-SW and ENE-WSW lineaments are cut across and counter clockwisely sheared by a N-S lineament in Makouma. These N-S lineaments are cross cut by the E-W to WNW-ESE lineaments. 
Stereogram of the directions and the cumulative directions from the overall lineament data display (Fig. 7b, 7c): (1) a NE-SW to ENE-WSW (N50E-N80E, averaged N60E-N70E) dominant direction corresponding to the direction of the Adamawa fault whose extension to Foumban is known as the CCC; (2) a secondary N-S (N170E-N10E) direction, (3) a NE-SW (N30E-N40E) direction corresponding to the direction the N30E-N50E branch of the CCC and the southern part of the and (4) a EW (N90E-N120E) to WNW-ESE (N120E-N140E) direction. On the Landsat images, the NE-SW and ENE-WSW lineaments are cross cut and counter clockwisely sheared by the N-S lineaments. These N-S lineaments are cross cut by the E-W to WNW-ESE lineaments.

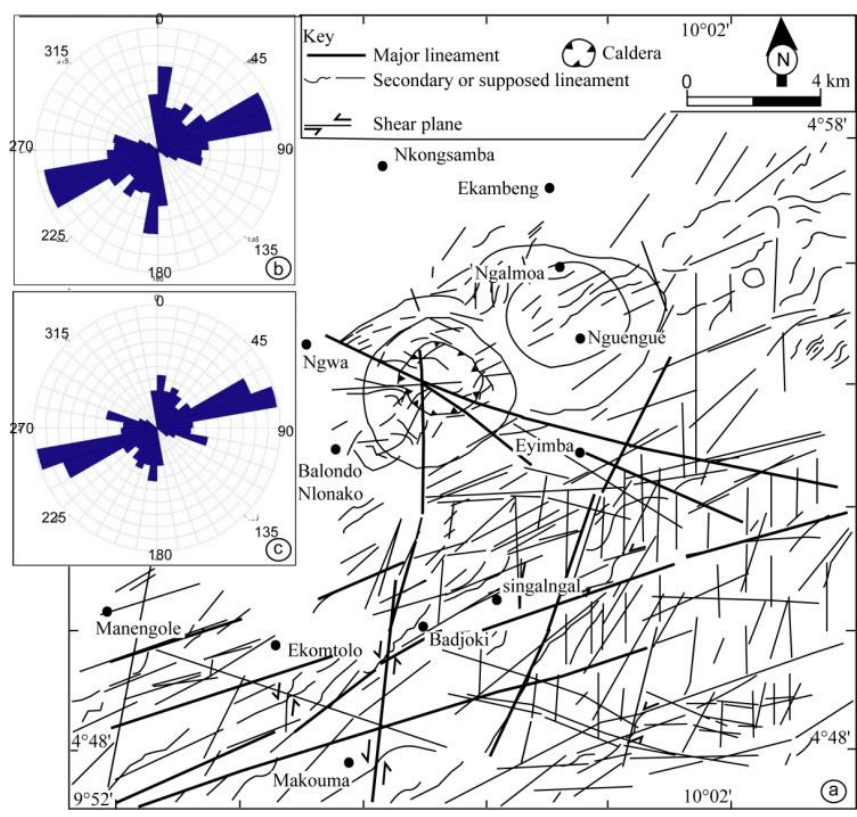

Fig. 7. Synthesis of lineament data. (a) Synthetic lineament map.

(b) Stereogram direction synthesis.

(c) Cumulative direction synthesis' stereogram.

\section{DISCUSSION}

A. Lineament distribution and contribution for the Nlonako complex shape determination

According to [9] and [14], NAC is a N-S elongated complex. However, the SRTM image (Fig. 8) indicates an egg-like intrusive body of about $10 \mathrm{~km}$ in diameter, oriented NNE-SSW from Ngalmoa to Balondo Nlonako [11]. In addition, data extracted from the Landsat 8 ETM+ image (Fig. 3) confirms this sub-circular shape. Moreover, field and petrographic data show that the NAC is a ring or annular complex (Fig. 15) slightly elongated in the NNESSW direction (Fig. 8; [11]), thus it can be called the Nlonako ring complex (NRC). The misinterpretation and miscorrelation for the determination of the annular or ring shape of the complex by [9] is likely due to the investigation techniques and the dense forest vegetation developed almost on the entire surface of the complex and, therefore, could not facilitate field investigations. For the present study, after field surveys, mathematical algorithms were applied to the Landsat 8 ETM+ image in order to remove vegetation before applying lineament extraction to the image. At the end of the application of this method, two distinct rings were identified on the lineament map (Fig. 5, Fig. 6, Fig. 7a). The superposition of lineament map with field data, a geological map from [11] and unpublished geochemical data shows that they are composed of (1) syenite for the well expressed biggest ring (Fig. 7a) and surroundings(2) and gabbro for the poorly express smallest ring. This ring shapes support the fact that the NRC is a ring complex slightly elongated toward NNE-SSW as concluded by [11] instead of displaying N-S shape as proposed by [9].

Map of lineament synthesis (Fig. 7) and the SRTM image (Fig. 8) show NE-SW, N-S and NW-SE trend structures. (1) The dominant NE-SW trend mostly displays by structures in the NRC and its basement rock is parallel to (i) the main metamorphic foliation trend (Fig. 2c, 2d) and (ii) to the central Cameroon shear zone regional fault. This direction also corresponds to the trend of the Ngondo pluton elongation and the regional foliation and structures [11] [15]. (2) The secondary N-S trend direction may correspond to the late deformational phase in the area. Indeed, these $\mathrm{N}$ S-related structures transposed NE-SW structures towards a meridional direction in the NRC basement rock, as shown by SRTM image (Fig. 8). (3) The NW-SE trend corresponds to the direction of NW-SE fault cross cutting the NRC and may also corresponds to the trend of early structures such as foliation. Indeed, according to [36] and [37], NW-SE foliation is generally remnant in the Pan-African Fold Belt in Cameroon; this may explain their relative scarcity in the belt.

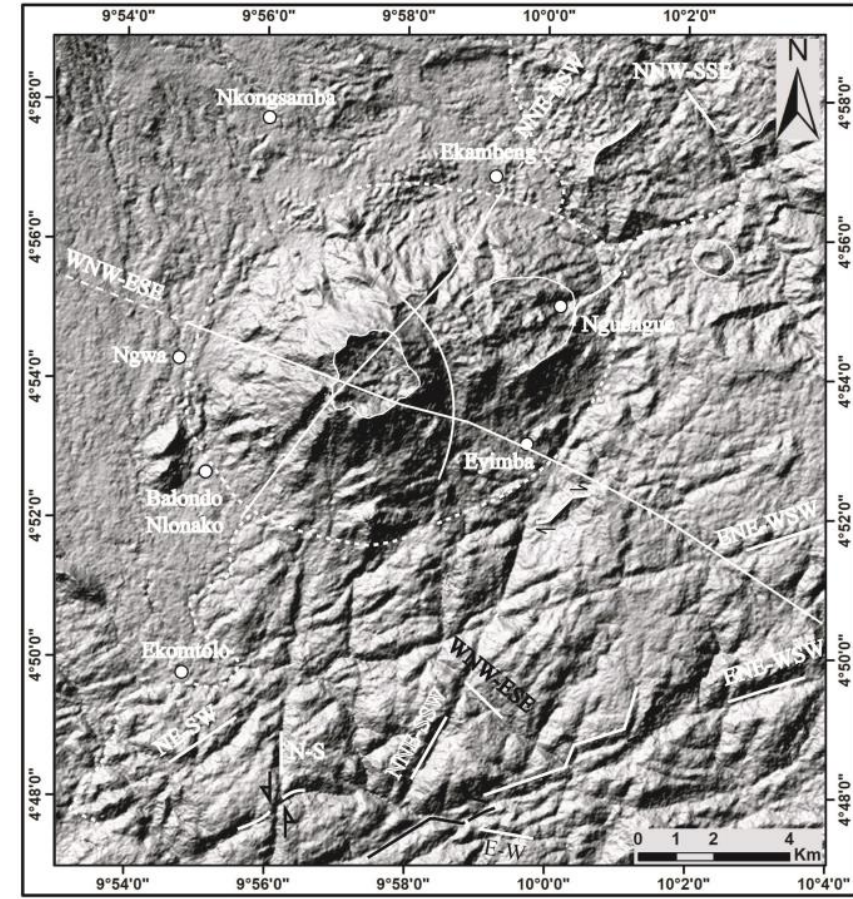

Fig. 2. SRTM image of the NRC showing its annular shape, slightly egglike shape elongated toward the NNE-SSW and displaying circular structures. Note also the WNW-ESE, E-W; ENE-WSW and NNE-SSW faults networks, dextral NE-SW and N-S sinistral shear markers.

\section{B. Contribution to Pan-African tectonic evolution}

Three main tectonic deformational phases are generally recorded in the Central Pan-African Fold belt in Cameroon 
[38]-[46]: (1) a Compressive deformational phase $\mathrm{D}_{1}$ whose main markers are NNW-SSE to NW-SE foliation; (2) an early left-lateral deformational phase $\mathrm{D}_{2}$ characterized by anticlockwise rotation and NE-SW sinistral transposition of early structures, and (3) a NE-SW late right-lateral deformational phase $\mathrm{D}_{3}$ marked by a clockwise rotation and a dextral transposition of preexisting structures [35]. However, recent research works from [47] and [35] described a late sinistral shear phase transposing NE-SW dextral $\mathrm{D}_{3}$-related structures, suggesting a more complex deformation history for the Pan-African Belt in Cameroon. The NW-SE foliation recorded by gneiss corresponds to the $S_{1}$, thus a $D_{1}$-related structure during the compressive tectonic. This NW-SE foliation is sheared and transposed by a sinistral shear deformation (Fig. 2b). NE-SW foliation $\left(S_{2}\right)$ still recorded in gneiss and the NE-SW magmatic foliation described in megacrysts granite from the Ngondo pluton by [11] and [15], are $\mathrm{D}_{2}$-related foliations. This NE-SW foliation also corresponds to the NE-SW $\mathrm{D}_{3}$ trend deformational phase since $\mathrm{D}_{2}$ and $\mathrm{D}_{3}$ phase display the same direction but of different sense of motion, that is left-lateral and right-lateral respectively for $D_{2}$ and $D_{3}$ [37]-[42], [45]. This is evidenced by the clockwise structures observed on the SRTM image of figure 8 . The relative absence of NE-SW sinistral shear markers on the SRTM image (Fig. 8) is probably due to the fact that they were overprinted by the NE-SW dextral shear phase structures [36][39], [42], [44]. The above deformational phases are usually described in the Central Pan-African Fold belt in Cameroon. In the study area, the SRTM image (Fig. 8) displays a N-S leftlateral movement overprinting and transposing the NE-SW right-lateral $\mathrm{D}_{3}$-related markers, suggesting a late $\mathrm{N}-\mathrm{S}$ sinistral phase $\mathrm{D}_{4}$ that follows the $\mathrm{D}_{3}$ deformational phase. Indeed, some recent research works in the Central Pan-African Fold belt in Cameroon [46], [35] demonstrated the occurrence of a late N-S left-lateral movement overprinting the $\mathrm{D}_{3} \mathrm{NE}-\mathrm{SW}$ right-lateral movement. The occurrence of sinistral N-S structure indicate that the tectonic history of the Pan-African Belt in Cameroon is more complex, and therefore display more than two shear phases but at least three, that is a right-lateral phase, sandwich by two left-lateral phase.

\section{CONCLUSION}

The NAC is located in the south western part of the Cameroon Line and superposed on the N50E branch of the central Cameroon shear zone. Landsat 8 ETM+ and SRTM images were used for lineament interpretation and tectonic reconstruction. Lineaments extracted from Landsat 8 ETM and SRTM images indicate a sub-circular shape for the NAC. Results from the combination of the above data, field and petrographic data from [46] showed that the NAC is a ring complex, thus it is called Nlonako ring complex (NRC). The map of lineament synthesis and the SRTM image of the study area display: (1) dominant NE-SW trend structures mostly displayed by the NRC and its basement rock corresponding to the direction of regional foliation and structures; (2) a secondary N-S trend direction that may corresponds to the late deformational phase in the area, and (3) NW-SE trend structures corresponds to the direction of NW-SE fault cross cutting the NRC and may also corresponds to the trend of early structures such as foliation. Fort deformational phases were identified from field data, lineament from Landsat 8 ETM+ and SRTM images: (1) a Compressive deformational phase $\mathrm{D}_{1}$, characterized by NNW-SSE to NW-SE $\mathrm{S}_{1}$ foliation; (2) an early NE-SW left-lateral deformational phase $\mathrm{D}_{2}$ whose structures were overprinted by a dextral shear deformation; (3) a NE-SW right-lateral deformational phase $\mathrm{D}_{3}$ marked by clockwise rotation and dextral transposition of preexisting structures and NE-SW S foliation; and (4) a N-S late sinistral shear phase $\mathrm{D}_{4}$ deformational phase which transposed the NESW dextral $\mathrm{D}_{3}$-related structures.

\section{ACKNOWLEDGMENT}

The authors express their warmest thanks to $\mathrm{Pr}$ KWEKAM Maurice whose strong comments substantially improve the quality of the first version of present manuscript. The authors give a warm thank the Nguengué, Eyimba and Balondo Nlonako populations especially to Mrs BONGUE ESSOH ABIA and KARI EBENE Hans for their multidimensional supports during field investigations which was an unconditional contribution that facilitate the lithostructural mapping of the NRC.

\section{REFERENCES}

[1] Jr. W.A., Beckman and E.H.T., Whitten. Statistical problems involved in remote sensing of the geology of the lithosphere-atmosphere interface. Journal of Geophysical Reseach vol. 71 (24), pp. 5873 5890, 1966. DOI: https://doi.org/10.1029/JZ071i024p05873.

[2] F.D., Van der Meer, H.M.A., Van Der Werff. Multi- and hyperspectral geologic remote sensing: a review. International Journal of Applied Earth Obs. Geoinformation, vol. 14 (1), pp. 112128, 2012.

[3] A., Bannari, A., El-Battay, A., Saquaque, A., Miri. PALSAR-FBS L$\mathrm{HH}$ mode and landsat-TM data fusion for geological mapping. Advance Remote Sensing vol. 5, pp. 246-268, 2016. https://doi.org/10.4236/ars.2016.54020.

[4] L.C., Rowan, J.C., Mars. Lithologic mapping in the mountain pass, California area using advanced space borne thermal emission and reflection radiometer (ASTER) data. Remote Sening Environment vol. 84 (3), pp. 350-366, 2003.

[5] X., Chen, T.A., Warner, D.J., Campagna. Integrating visible, nearinfrared and short-wave infrared hyperspectral and multispectral thermal imagery for geological mapping at Cuprite, Nevada. Remote Sensing Environment, vol. 110, pp 244-256, 2007.

[6] L., Yu, A., Porwal, E.-J., Holden, M.C., Dentith. Towards automatic lithological classification from remote sensing data using support vector machines. Computer Geoscience, vol. 45 (Supplement C), pp. 229-239, 2012.

[7] S.C., Nguemhe Fils, C.H., Bekele Mongo, D.G., Nkouathio, M.E., Mimba, J., Etouna, P., Njandjock Nouck, B., Nyeck. Radarsat-1 image processing for regional-scale geological mapping with mining vocation under dense vegetation and equatorial climate environment, Southwestern Cameroon. The Egyptian Journal of Remote Sensing and Space Sciences, vol. 46 (9), pp. 1-13, 2018.

[8] J.C., Dumort 1968. Notice explicative sur la feuille Douala-Ouest avec carte géologique au 1:500000. Imprimerie nationale Yaounde Cameroun.

[9] M.G. Abolo, D. Lamilen, I. Ngounouno, D. Bitom, Petrography and mineralogy of the Nlonako anorogenic complex rocks, Central Africa: petrogenetic implications. Sciences, Technologies et Développement, vol. 15, pp. 32-42, 2014

[10] F.M., Henderson, A.J., Lewis. Principles and Applications of Imaging Radar. Manual of Remote Sensing. In: American Society for Photogrammetry and Remote Sensing. Third ed. John Wiley \& Sons Inc, Canada, p. 866, 1998. 
[11] J.A., Noudiedie Kamgang, J., Tcheumenak Kouemo, A., Kagou Dongmo, E.M. Fozing, S.C. Choumélé Kana, J., Efon Awoum, G.R., Kenfack Nguemo. Emplacement and evolution of the Nlonako ring complex in the southern domain of the cameroon Line. European Journal of Environment and Earth Sciences vol. 1 (4), pp. 1-10, 2020. DOI: http://dx.doi.org/10.24018/ejgeo.2020.1.4.45

[12] M., Lasserre. Mise au point sur les granitoïdes dits "ultimes" du Cameroun : gisements, pétrographie et géochronologie. Bulletin bureau de recherches géologiques et minières vol. 4, pp. 143-156, 1978.

[13] J. M., Cantagrel, C., Jamond, M., Lasserre. Le magmatisme alcalin de la ligne du Cameroun au Tertiaire inférieur : données géochronologiques $\mathrm{K} / \mathrm{Ar}$. Comptes Rendus Bulletin de la Société Géologique de France, vol. 6, pp. 300-303, 1978

[14] M.G. Abolo, D. Lamilen, I. Ngounouno, D., Bitom. Geochemistry and Geochronology of the Nlonako Alkaline Complex, Central Africa.Journal of the Cameroon Academy of Sciences, vol. 12, pp. 3344, 2015.

[15] G, Tagne Kamga, E, Mercier, M, Rossy, N.E., Nsifa. Synkinematic emplacement of the Pan-African Ngondo igneous complex (Wes Cameroon, Central Africa). Journal of African Earth Science vol. 28 pp. 675-691. 1999.

[16] E., Njonfang, G., Tchuenté Tchoneng, D., Cozzupoli, F., Lucci. Petrogenesis of the Sabongari alkaline complex, Cameroon line (central Africa): Preliminary petrological and geochemical constraints. Journal of African Earth Sciences, vol 83, pp. 25-54, 2013.

[17] A.K., Jain, M., Tuceryan. "Texture analysis", chapter 11 in the Handbook of pattern recognition and computer vision by C.H. Chen, 1992.

[18] R.M., Haralick. Statistical and structural approaches to texture. Proc.

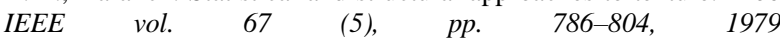
https://doi.org/10.1109/PROC.1979.11328

[19] T.B., Reed IV, D. M., Hnssong, 1989. Digital image processing techniques for enhacement and classification of SeaMARC II side scan sonar imagery. Journal of Geophysical Research vol. 94 (B6), pp. $7469-7749$

[20] G.A., Azzibrouck, R., Saint-Jean, C., Prévost. Analyse de la texture d'une image RADARSAT pour la cartographie géologique dans la Forêt Équatoriale de Ngoutou, est du Gabon. Proceedings of Geomatics in the Era of RADARSAT (GER'97), 1997.

[21] P., Dong, B., Leblon, 2004. Rock unit discrimination on Landsat TM, SIR-C and Radarsat images using spectral and textural information. Intiternational Journal of Remote Sensing vol. 25, pp 3745-3768.

[22] Li, N., 2010. Textural and Rule-based Lithological Classification of Remote Sensing Data, and Geological Mapping in Southwestern Prieska Sub-basin, Transvaal Super group, South Africa Dissertation. LMU München: Faculty of Geosciences.

[23] M., Sukumar, S. Selva Meenambihai. Discriminating lineaments from the aster image by analyzing the object properties. International Journal of Advanced Technology and Engineering Science vol. 3(01), pp 2348-7550, 2015

[24] N., Hammad, M., Djidel, N., Maabedi. Cartographie des linéaments géologiques en domaine aride par extraction semi-automatique partir d'images satellitaires: Exemple à la région d'El Kseïbat (Sahara algérien). Estudia Geology. Vol. 72 (1) 2016, e049. https://doi.org/10.3989/egeol.42158.377.

[25] T.M., Lillesand, R.W., Kiefer, W.C., Jonathan. Remote sensing and image interpretation. John Wiley\& Sons Inc, pp. 663-666, 2004.

[26] F., Kouamé, P., Gioan, J., Biemi, K., Affian. Méthodes de cartographie desdiscontinuités -images extraites d'images satellitales: exemple de la régionsemi-montagneuse à l'ouest de la côte d'Ivoire. Revue de Télédétection vol. 1 (2), pp. 139-156, 1999.

[27] M.A., Juhari,. Lineaments in enhanced remote sensing images: an example from the Upper Perak Valley, Perak Darul Ridwan. Geological Society of Malaysia Bulletin, vol. 48, pp. 115-119, 2004.

[28] I., Umikaltuma, F., Mutua, Lineament extraction using landsat 8 (OLI) in Gedo, Somalia. International Journal of Science Research 2319-7064, 2012

[29] S., Gannouni, H., Gabtni. Structural interpretation of lineaments by satellite image processing (landsat TM) in the region of zahretmedien (Northern Tunisia). Journal of Geographical Information System, vol. 7, pp. 119-12, 2015. DOI: https://doi.org/10.4236/jgis.2015.72011.

[30] N., Hammad, M., Djidel, N., Maabedi. Cartographie des linéaments géologiques en domaine aride par extraction semi-automatique à partir d'images satellitaires: Exemple à la région d'El Kseïbat (Sahara algérien). Estudia Geology vol. 72 (1), 2016 e049. DOI: https://doi.org/10.3989/egeol.42158.377.
[31] K., El-Sawy, El-Sawy, M., Ibrahim, Atef, A., El-Bastawesy, Mohamed, A., El-Saud, Waleed. Automated, manual lineaments extraction and geospatial analysis for Cairo-Suez district (Northeastern Cairo-Egypt), using remote sensing and GIS.International Journal of Innovative Science Engineering and Technology 3 (5), 2016.

[32] S., Khosroshahizadeh, M., Pourkermani, M., Almasian, M., Arian, A., Khakzad. Lineament patterns and mineralization related to alteration zone by using ASAR-ASTER imagery in hizejan-sharafabad au-ag epithermal mineralized zone (east azarbaijan-NW Iran). Open Journal of Geology vol. 6, pp. 232-250, 2016. DOI https://doi.org/10.4236/ojg.2016.64021.

[33] F., Masoumi, T., Eslamkish, A.A., Abkar, M., Honarmand, J.R., Harris. Integration of spectral, thermal, and textural features of ASTER data usingRandom Forests classification for lithological mapping. Journal of African Earth Science, 2017. DOI https://doi.org/10.1016/j.jafrearsci.2017.01.028.

[34] M., Hall-Beyer, A., Srivastava. Principal components of GLCM texturemeasures: what can they tell us and are they useful? International Geoscience Remote Sensing Symposium (IGARSS), 32, 2006.

[35] Zhi-Kai Huang, Pei-Wu Li, Ling-Ying Hou, 2009. Segmentation of Textures using PCAFusion Based Gray-Level Co-Occurrence Matrix Features. International Conference on Test and Measurement. pp 103-105, 2009.

[36] J., Efon Awoum, E.M., Fozing, M., Kwékam, J., Tcheumenak Kouémo, S.C., Choumele Kana, L. Achu Megnemo. Structura characterization of the Pan-African Ndieki area in the FoumbanBankim Shear Zone (West Cameroon): constraints from field observations and microstructures. Arabian Journal of Geoscience vol. 13, pp. 831, 2020.

[37] E. M. Fozing, M. Kwékam, J. Tcheumenak Kouémo, T. Njanko, E. Njonfang. Kinematic analysis of the Dschang granitic pluton (WestCameroon): Implications to the Pan-African deformation of the Central African Fold belt in Cameroon during the post-collisional history of western Gondwana. Precambrian research, under review, 2020

[38] V., Ngako, P., Affaton, J.M., Nnange, T., Njanko, Pan-African tectonic evolution in central and southern Cameroon: transpression and transtension during sinistral shear movements. Journal of African Earth Sciences vol. 36, pp. 207-214, 2003.

[39] V., Ngako, P., Affaton, E., Njonfang. Pan-African tectonics in Northwestern Cameroun: implication for the history of western Gondwana. Gondwana Research vol. 14, pp. 510-511, 2008.

[40] E., Njonfang, V., Ngako, C., Moreau, P., Affaton, H., Diot Restraining bends in high temperature shear zones: the "Central Cameroon Shear Zone", Central Africa. Journal of African Earth Science, vol. 52, pp 10-11-12, 2008.

[41] M., Kwékam, J.P., Liégeois, E., Njonfang, P., Affaton, G., Hartmann, F., Tchoua. Nature, origin and significance of the Fomopéa PanAfrican high-K calc-alkaline plutonic complex in the central African fold belt in Cameroun. Journal of African Earth Science, vol. 57, pp. 79-95, 2010.

[42] T., Njanko, A., Nédélec, M., Kwékam, R., Siqueira, L., Esteban. Emplacement and deformation of the Fomopéa pluton: implication for the Pan-African history of Western Cameroon. Journal of Structural Geology vol. 32, pp. 306-320, 2010.

[43] J., Tcheumenak Kouémo, T., Njanko, M., Kwékam, S., Naba, B.E. Bella Nke, A.F., YakeuSandjo, E.M., Fozing, E., Njonfang. Kinematic evolution of the Fondjomekwet-Fotouni shear zone: Implication for emplacement of the Fomopéa and Bandja plutons. Journal of African Earth Sciences, vol. 99, pp. 261-275, 201.

[44] E.M., Fozing, T., Njanko, N., Seta, M., Kwekam, E., Njonfang, P., Rochette. Structural characterization of the Misajé granitic pluton (NW Cameroon): constraints from magnetic and field observations International Journal of Earth Science vol. 105, pp. 2285-2309, 2016.

[45] E.M., Fozing, A.C., Mengou,T., Njanko, A., Téfo Fokoua, I.K., Tiseh, M., Kwékam, C., Chatué Njiki. Emplacement of the Dschang granitic pluton (West Cameroon): Constraints from microstructures and magnetic fabrics. Journal of African Earth Science vol. 156, 144-157, 2019.

[46] E., Nomo Negue, R., Tchameni, O., Vanderhaeghe, F., Sun, P., Barbey, L., Tekoum Fosso P.M., Tchunte, A., Eglinger, N.A., Sah Fouotsa. Structure and LA-ICP-MS zircon U-Pb dating of syntectonic plutons emplaced in the Pan-African Banyo-Tcholliré e shear zone (central north Cameroon). Journal of African Earth Science vol. 131, pp 251-271, 2017 
European Journal of Environment and Earth Sciences www.ej-geo.org

[47] B., Ntieche, M., Ram Mohan, M., Amidou. Granitoids of the Magba Shear Zone, West Cameroon, Central Africa: evidences for emplacement under transpressive tectonic regime. Journal of Geological Society of India vol. 89, pp 33-46, 2017.

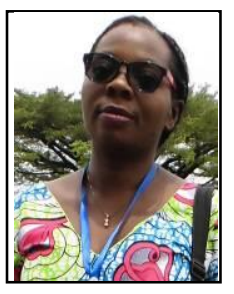

J. A. Noudiedie Kamgang is a Master degrees holder in structural geology, University of Dschang, Cameroon, 2015.

She is still $\mathrm{Ph} . \mathrm{D}$ candidate at the same University.

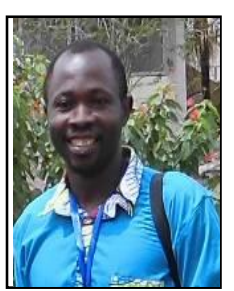

J. Tcheumenak Kouémo is a Ph.D holder in Structural Geology and metamorphic petrology at the University of Dschang, Cameroon, 2018.

Dr Tcheumenak Kouémo is Lecturer at the University of Douala, Cameroon. 